\title{
LAS INFANTAS DE LINA MERUANE: UN TEJIDO DE TRADICIONES REVISADAS BAJO LA ESTÉTICA NEOBARROCA
}

\section{Nerea Oreja Garralda}

Universidad Católica Argentina

nereaog@gmail.com

Resumen: El objetivo de este trabajo es analizar Las Infantas (1998) de Lina Meruane como una recopilación de cuentos integrados que, bajo los preceptos de la estética barroca y neobarroca delineados por Severo Sarduy, se construye como un tejido de entrecruzamientos e hibridaciones entre diversas tradiciones, con un afán crítico y subversivo propio también de la posmodernidad. Lo clásico, sobre todo aquello relacionado con la literatura infantil, se adopta y se adapta a un nuevo contexto.

Palabras clave: Las Infantas, Lina Meruane, hibridez, posmodernidad, neobarroco

\begin{abstract}
The objective of this paper is to analyze Lina Meruane's Las Infantas (1998) as an integrated tales collection that, under the precepts of the baroque and neo-baroque aesthetic described by Severo Sarduy, is constructed as a hybrid texture of different traditions, with a postmodern subversive effort. Classic literature, especially that related to children, is adopted and arranged to a new context.
\end{abstract}

Keywords: Las Infantas, Lina Meruane, hybridity, postmodernism, Neo-Baroque

DOI: $\underline{\text { htps://doi.org/10.24029/lejana.2017.10.166 }}$

Recibido: el 1 de julio de 2017

Aceptado: el 27 de octubre de 2017

Publicado: el 4 de noviembre de 2017 
Yo, en cambio, entre sapos y culebras, escribo. Con todas las letras escribo, con todas las palabras trato de narrar la otra cara de una historia de escisiones que a mi me difama.

(Simetrías, Luisa Valenzuela)

\section{Introducción}

Las Infantas (1998) de la escritora chilena Lina Meruane es un texto a priori difícil de definir. ¿Hablamos de una novela o de una recopilación de cuentos? Ambos términos serían aplicables y correctos, pero aquí nos decantamos por el segundo de ellos, siguiendo la lógica empleada por Francisca Noguerol a la hora de analizar las relaciones entre los relatos que integran los Cuentos de Hades incluidos en el volumen Simetrías (1993) de Luisa Valenzuela, referente de la relectura de los cuentos infantiles en América Latina. ${ }^{1}$ Si bien el caso de Las Infantas supone un desafío de mayor envergadura a la hora de ser taxonomizado, en el texto "el carácter de ciclo cuentístico se encuentra reforzado por la reiteración de temas, personajes y contextos" (Noguerol, 2006: 393), condición que nos permite hablar de un volumen de cuentos integrados.

Las Infantas contiene veintiún relatos, diez de los cuales son diversos episodios de la historia de las dos hermanas, Hildeblanca y Hildegreta, en una revisión paródica de los cuentos de hadas. Los once relatos restantes se intercalan con la historia principal, y cada uno de ellos constituye una narración autónoma, cerrada, pero con elementos que la relacionan con la historia principal. Los personajes de los cuentos que conforman esta línea de narración son metamorfosis grotescas de las princesas protagonistas de la historia central. Estos dos tipos de relatos intercalados se diferencian, además, por la tipografía empleada en unos y otros. Los episodios relativos a la línea argumental que narra las peripecias de las dos hermanas aparecen en cursiva, ${ }^{2}$ con letra minúscula en los títulos y con un paréntesis, dentro del cual se incluye una oración introducida por la fórmula de cómo... que remite a la acción principal del relato en cuestión. ${ }^{3}$ Los títulos de la otra línea de cuentos aparecen en letra minúscula y no remiten a acciones concretas ("pasos en falso", "de mano en mano", "grabado sobre lámina”, etc.). Los títulos en minúscula, por su parte, representan la oposición a la mayúscula tradicional, al relato oficial y normativo.

Este tipo de estructuración de los relatos, así como su contenido plagado de desdoblamientos, sigue la estela de la noción barroca de la multiplicidad, elaborada por

\footnotetext{
${ }^{1}$ Serán numerosos los puntos de encuentro entre ambas autoras en sus revisiones de los cuentos infantiles tradicionales, aunque cada una de ellas imprime una perspectiva personal y deja entrever los temas que le preocupa resaltar y subvertir. Los puntos en común con Valenzuela se observarán sobre todo en el apartado 2.1., donde se analizan la tradición y las relecturas de dichos cuentos. Como se verá más adelante, algunos de los relatos de Meruane siguen la línea paródica trabajada en América Latina por la autora argentina, de ahí que su mención sea imprescindible.

${ }^{2}$ La letra cursiva o bastardilla imita a la manuscrita. Meruane ha podido emplear este recurso para remitir a la idea del cuento tradicional, original, como aquellos recopilados por Perrault en Francia o por los Hermanos Grimm en Alemania. De este modo, los cuentos sobre estas dos hermanas constituirían una especie de manuscrito que contiene la cara B de la tradición infantil.

${ }^{3}$ Los subtítulos con la forma de cómo..., donde..., cuando..., seguidos del resumen de la acción principal del capítulo, son propios de la literatura medieval. La aparición de esta forma en los cuentos de Meruane remite a esa tradición, imitando el modelo y, al mismo tiempo, subvirtiéndolo.
} 
Severo Sarduy y que marcará la línea estética de Las Infantas. ${ }^{4}$ Para Sarduy, el barroco surge como modo de reacción ante la inexistencia de un sentido único y de una verdad unívoca, cuando el mundo ya no es aprehensible desde una perspectiva totalizante, instaurándose de este modo un "pensamiento de la infinitud, de lo no centrado, sin lugares ni espesores precisos" (1974: 56). En este sentido, el barroco se erige como movimiento del descentramiento, ligado a la imagen de la elipse frente al círculo de la era clásica (la elipse, al fin, como círculo descentrado). La imposibilidad de un punto de vista único y totalizante, la incapacidad de adoptar un discurso universal, lleva a una forzosa reestructuración de la escritura a partir de la idea del residuo de lo anterior, de los grandes discursos. El punto de vista ya no será único, sino "el espejo de una ambigüedad" (Sarduy, 1987: 101), y el discurso se construirá a base de una focalización múltiple de variados puntos de vista que convierte lo mismo en lo otro en un intento de que "cada nueva percepción llegue a enunciarse a partir de ese punto absoluto y anónimo que se sitúa por definición más allá del alcance de toda experiencia posible: focus imaginarius que es a la vez fin de la subjetividad y de la contingencia, fundamento y límite del logos, silencio" (Sarduy, 1974: 90). Las constantes metamorfosis de las infantas van en pos de las múltiples focalizaciones que señala Sarduy, hilando un texto polifónico en términos bajtinianos $\mathrm{y}$, siguiendo esta misma estela, carnavalesco, donde nada es lo que parece y nadie es quien dice ser. Esta ambigüedad entre el ser y el parecer es otro de los grandes tópicos del barroco, que posibilita, como en el texto de Meruane, el juego especular del sujeto escindido o del doble.

En relación a esta construcción textual a partir del residuo ${ }^{5}$ y la dispersión del sujeto en múltiples voces, Sarduy insinúa la metáfora del texto como universo a través de la imagen del Big Bang. La teorización iniciada por el jesuita belga Lemaître se corresponde así con el planteamiento barroco y su línea de pensamiento: "un estadio de génesis, puntual, metáfora del verbo y el semen / un estadio de crecimiento, metáfora de la multiplicación, del núcleo primigenio diseminado, pero también de la corrupción y del exilio / un apagón apocalíptico final, disolución en el vacío, ausencia del sentido" (Sarduy, 1974: 97). Tal sucesión de hechos o, más concretamente, de estadios es observable en el texto de Meruane y en la estructuración de los relatos en la compilación que es Las Infantas, así como en el modo en que los personajes transitan el recorrido que es la vida bajo la metáfora del bosque ${ }^{6} \mathrm{y}$ de la ciudad.

Por otro lado, la ambigüedad genérica de este texto responde igualmente a una visión posmoderna de límites difuminados y fronteras extintas (propia del momento en el que se

\footnotetext{
${ }^{4}$ Tanto en Barroco (1974) como en Ensayos generales sobre el barroco (1987), Sarduy expone su mirada sobre la estética barroca, que constituye una concepción crítica ante un momento de crisis en la sociedad. Los elementos expuestos por el cubano emergerán a lo largo de este trabajo, como modo de enmarcar la escritura que Meruane desarrolla en Las Infantas.

${ }^{5}$ Es interesante resaltar cómo Sarduy contextualiza esa ruina de gran potencia creativa en América Latina: "Ese barroco furioso, impugnador y nuevo no puede surgir más que en las márgenes críticas o violentas de una gran superficie — de lenguaje, ideología o civilización-: en el espacio a la vez lateral y abierto, superpuesto, excéntrico y dialectal de América: borde y denegación, desplazamiento y ruina de la superficie renaciente española, éxodo, trasplante y fin de un lenguaje, de un saber" (1987: 101, cursiva en el original). Este sería también el margen desde el que Meruane escribe.

${ }^{6}$ Como veremos, el imaginario que los cuentos infantiles construyen en torno al bosque adquiere nuevos significados en Las Infantas, y ya en los Cuentos de Hades de Valenzuela (sobre todo en "Si esto es la vida, yo soy Caperucita Roja"); así lo analiza María José Punte (2013b) al estudiar la tradición de la literatura infantil, y aquí lo trabajaremos a la hora de observar la vuelta de tuerca que Meruane da a los cuentos de hadas tradicionales.
} 
escribió), muestra de la "crisis de la noción de totalidad" (García Canclini, 1992: 329), idea ya presente en el barroco. Como modo de reacción ante la falta de paradigmas o de referentes legítimos y sólidos, el arte y, por tanto, la literatura, se erigen como desafío. Y este desafío, que abarca tanto la forma como el contenido, está marcado por el carácter de hibridez o hibridación (García Canclini, 1992) que pasará a ser una categoría descriptiva común, junto a aquella de transculturación (acuñada por el antropólogo cubano Fernando Ortiz en 1940 y trabajada posteriormente por Ángel Rama a partir de la década del 70) y la de heterogeneidad cultural, revisión crítica que Antonio Cornejo-Polar hizo del planteo de Rama. Si bien estas últimas dos categorías sirvieron en su momento para describir la realidad latinoamericana, diversos autores han mostrado sus límites o, como en el caso de Raúl Bueno, han matizado su definición y alcance. Según Bueno, la transculturación no se opone a la heterogeneidad, como han defendido otros autores, sino que ambas categorías se complementan. "La transculturación no es propiamente una categoría descriptiva de la realidad latinoamericana, como la heterogeneidad o - parcialmente - el mestizaje, sino una parte destacada de las dinámicas de heterogeneidad" (Bueno Chávez, 2009: 31), tesis a la que también se adherirá David Sobrevilla, quien ratifica que "dada una situación de heterogeneidad de culturas, una puede someterse a la otra y recibir pasivamente sus elementos — esta es la dinámica aculturadora-, o asimilar creadoramente dichos elementos a partir de su propia matriz —el caso de la dinámica transculturadora" (2001: 29). ${ }^{7}$

Para analizar Las Infantas nos atendremos a la categoría de la hibridez expuesta por García Canclini por considerarla la más adecuada para tal fin. Como hemos afirmado anteriormente, el texto de Meruane se inscribe dentro del posmodernismo, que "no es un estilo sino la copresencia tumultuosa de todos" (García Canclini, 1992: 307), definición que nos lleva a pensar inmediatamente en una estética híbrida que aúne la multiplicidad de discursos y tradiciones. Esta hibridación deshace los órdenes convencionales y resulta fecunda a la hora de hacer emerger nuevas y desafiantes rupturas. De ahí su potencial crítico.

Las Infantas es un exponente de dicha hibridez en tres niveles: el nivel del texto, entendido aquí como tejido (en su carácter etimológico de textus) de tradiciones y discursos provenientes de diversas culturas; el nivel de la estructuración de la narración, como imbricación de dos líneas narrativas autónomas pero, a su vez, entrecruzadas por una serie de elementos-puente; y el nivel de los personajes y el modo en el que estos se construyen como sujetos. En este caso centraremos el análisis en el primero de los niveles.

Por último, este conjunto de tradiciones, este tejido híbrido que se enmarca en la línea de lo posmoderno, se presenta, como ya se ha mencionado, bajo el signo de la estética barroca y, más concretamente, neobarroca, según la definición elaborada por Sarduy, quien lo expone como un "barroco que recusa toda instauración, que metaforiza al orden discutido, al dios juzgado, a la ley transgredida. Barroco de la Revolución” (1974: 104). ${ }^{8}$ El epígrafe con el que

\footnotetext{
${ }^{7}$ En el caso de Las Infantas se observa una dinámica de transculturación, ya que el texto recoge tradiciones occidentales (en concreto, europeas) pero las trabaja desde el contexto chileno, situando los hechos, aunque de manera no explícita, en el Chile de la dictadura. De este modo, lo europeo se tiñe, por decirlo de un modo gráfico, de elementos propios chilenos como puede ser el lenguaje. Sin embargo, dicho proceso de transculturación se da, como exponen Bueno y Sobrevilla, sobre una base previa ya heterogénea.

${ }^{8}$ El carácter revolucionario que Sarduy le atribuye a la estética neobarroca posibilita una lectura política de la misma. De ahí que, en el caso de Las Infantas, esta especie de rebelión textual (así como sexual) sea digna de leerse bajo la misma clave.
} 
empieza Las Infantas nos remite al autor cubano y abre la posibilidad de leer el texto en clave (neo)barroca: "todas las cicatrices remiten a una sola; la primera, la escisión umbilical, la única invisible". Como se verá más adelante, la importancia del cordón y de lo umbilical como lazo con lo materno (que, sin embargo, se caracteriza por su ausencia) será fundamental a lo largo de todos los relatos.

En este punto, la estética posmoderna y la barroca (y su elevación a la máxima potencia que será el neobarroco) se tocan, se revelan de un modo muy similar contra aquello que las precede. Podrían definirse ambas como cierta enfermedad, cierta irrupción maligna y desestructuradora en el orden establecido. Y esta idea de lo enfermo como ataque repentino, como otro que es parte de lo mismo, nos lleva a la metáfora del intruso expuesta por Jean-Luc Nancy y que puede expresar igualmente la condición barroca y posmoderna en la sociedad y, más concretamente, en la literatura: "El intruso se introduce por fuerza, por sorpresa, por astucia; en todo caso, sin derecho y sin haber sido admitido de antemano" (11). . Así irrumpe también el barroco en relación a lo clásico y la posmodernidad frente a la modernidad, siendo ambas rupturas exponentes de "tiempos locales, fragmentados, contradictorios, envolventes; espacios variables, condicionados por la situación del que los mide” (Sarduy, 1974: 85).

\section{Textus: un tejido de tradiciones}

Las Infantas es un compendio de diversas tradiciones imbricadas que, sin embargo, responden a un mismo fin: deconstruir los discursos convencionales para, a partir de ahí, construir una nueva mirada sobre la infancia y, a través de la misma, mostrar una realidad en ruinas: la de la dictadura militar chilena que la propia Meruane vivió en su infancia y adolescencia. Para tejer esta perspectiva crítica, acorde con los preceptos revolucionarios del neobarroco de Sarduy, la autora se vale de discursos canónicos de la tradición cultural occidental y los somete a una revisión donde el infante es el centro de sucesivas peripecias que constituyen una suerte de viaje iniciático grotesco hacia la vida adulta.

\subsection{Los cuentos de hadas}

Según Noguerol, "el cuento de hadas, más allá de las diferencias raciales y culturales, maneja un lenguaje universal que le permite emigrar sin problemas de una zona a otra del planeta. Este hecho, junto a su carácter arquetípico, explica su éxito en las culturas más diferentes" (2001: 195). La plasticidad de estos cuentos, como ocurre también con los mitos, permite desacralizar las formas consagradas por la tradición para resignificarlas en un nuevo contexto. En 1979, Angela Carter publicó The Bloody Chamber and Other Stories, donde somete a una revisión feminista a los cuentos de hadas tradicionales. Si bien puede considerarse la pionera de la línea de las (per)versiones de los cuentos infantiles, en este caso tomaremos como referencia de algunos aspectos de Meruane a Luisa Valenzuela, por escribir también desde los márgenes de los que habla Sarduy, es decir, desde América Latina, partiendo de tradiciones europeas y estableciendo de este modo un diálogo inter-semiótico.

\footnotetext{
${ }^{9}$ En sucesivos trabajos veremos cómo, en la construcción del sujeto en Las Infantas, el intruso llega a ser uno mismo. El intruso como el otro que habita en mí, como sucede, por ejemplo, en la dupla niña-lobo (o mujer-lobo en una tradición literaria más amplia) en Meruane. El intruso ya no se vive como lo ajeno sino como lo propio que, sin embargo, conserva cierto carácter de otredad que provoca inquietud.
} 
Los cuentos de hadas, insertos en la más amplia tradición de la literatura infantil, han sido transmitidos a lo largo de los siglos como relatos cuya finalidad es instruir a los infantes en los pormenores de la vida diaria, en asuntos relacionados con el amor, las amistades convenientes o inconvenientes, la curiosidad y sus consecuencias, la paciencia, las buenas virtudes, etc. Estos cuentos, recopilados por Charles Perrault a finales del siglo XVII, ${ }^{10}$ contenían al final de cada relato una moraleja en la que, de manera explícita y sin metáforas, se aludía a la enseñanza concreta que había que tomar de dicha historia. En muchos casos, los cuentos de hadas tenían moralejas destinadas únicamente a las niñas, con el propósitos de que estas se guardaran de determinados peligros relacionados con hombres de malas intenciones.

Es por todos conocido que el universo de los cuentos de hadas está habitado por bellas princesas, hermosos príncipes, hadas madrinas, la mayoría de ellas bondadosas pero entre las que se encuentra alguna malvada (como la que lanza el conjuro a la joven princesa de "La Bella Durmiente"), cazadores salvadores, leñadores amistosos, suegras en ocasiones amables y en otras descendientes de ogros, enanos, espejos que hablan, brujas que viven en los bosques, lugares encantados, animales que hablan, padres protectores y madres que fallecen jóvenes y son sustituidas por horribles madrastras, etc. ${ }^{11}$

Según Bruno Bettelheim (1977), el objetivo del cuento de hadas es brindar soluciones para los temores producidos por ciertas pulsiones, aliviándolas, y ofrecer siempre un desenlace feliz a los problemas. Por eso, los cuentos de hadas son relatos optimistas que consuelan después del temor causado por la trama, y cuyos personajes adquieren la categoría de héroes. ${ }^{12}$ El relato, por tanto, adquiere un sentido de rito de pasaje (Bettelheim) del sujeto hacia una nueva forma de existencia, considerada superior. En muchos de los cuentos, este pasaje responde a la metáfora del bosque, camino que el/la protagonista deberá recorrer; al final de este recorrido, al salir del bosque, el personaje tendrá una "estructura humana muy superior" (Bettelheim, 1977: 133), precepto que no parece cumplirse en el caso de Las Infantas. En los cuentos de Meruane, el recorrido vital realizado por las dos hermanas a través, primero, del bosque y posteriormente de la ciudad moderna (un Santiago desfigurado), si bien es un rito de pasaje o viaje iniciático, no las conduce a un estadio superior del ser, sino que las convierte en sujetos abyectos, protagonistas de actos criminales como el asesinato de la dueña de la pensión o el de Hans. La idea del periplo que viven las dos hermanas se corresponde con la noción del barroco como espacio de viaje, una "travesía de la repetición" (Sarduy, 1974: 62), un recorrido caracterizado por lo circular, por el retorno al inicio, en un

\footnotetext{
${ }^{10}$ En este texto se tendrá en cuenta esta fuente, a pesar de que existe también la recopilación realizada por los Hermanos Grimm a principio del siglo XIX. En Las Infantas se hace mención explícita a Perrault, cuando Greta debe asistir al juicio por el asesinato que, supuestamente, Blanca ha cometido. Allí, debe prestar juramento ante el texto del autor francés, que adquiere estatus de Biblia: "Juro ante Perrault, uf, qué feo nombre... Juro ante el señor Perrault Todopoderoso... Excúseme, señor, Su Señoría, ¿qué cosa os debía jurar?” (2010: 128).

${ }^{11}$ Normalmente, todos estos personajes aparecen sin nombres propios, ya que son personajes tipo que condensan una serie de rasgos conocidos y reconocibles por los niños, facilitando así las identificaciones y las proyecciones de estos con aquellos (Bettelheim). En el caso de que tengan un nombre propio, como, por ejemplo, Hansel y Gretel, estos se tornan términos casi genéricos, aplicables a cualquier niño y con los que estos pueden identificarse.

${ }^{12}$ Bettelheim diferencia el mito del cuento de hadas en virtud del héroe. En el mito, el héroe responde a las demandas del Super-Yo freudiano (reflejo de las normas morales y éticas de la sociedad en la que vive) y, en el cuento de hadas, se corresponde con las exigencias del Ello (el nivel del inconsciente y los instintos más primitivos).
} 
tiempo laberíntico que nos lleva a pensar en el concepto del eterno retorno, presente en Las Infantas, de manera explícita en el último relato.

Pero vayamos por partes. En primer lugar, los relatos no se sitúan en un lejano país de nunca jamás cuyas historias comienzan siempre con un ambiguo Érase una vez. En el caso de las narraciones en torno a Hildeblanca y Hildegreta, ${ }^{13}$ no se muestran anclajes espaciotemporales concretos, pero sí indicios de que podemos apuntar al Chile de la dictadura militar (1973-1990), con vagas alusiones a la ciudad como espacio desolado y de represión. Unida a esta idea, como espacio barroco por excelencia nace la imagen y el imaginario ligado a lo urbano, a la ciudad como topos abierto, sin un significante único privilegiado gracias al cual adquiera sentido. ${ }^{14}$ Como elementos indiciales que remiten al contexto histórico mencionado, podemos observar los desaparecidos cuyos huesos buscan los doce enanos en el monte, para así confeccionar largas listas de correspondencia entre las osamentas halladas y las personas desaparecidas; del mismo modo, la figura del padre, de connotaciones negativas debido a la adicción al juego, la ruina en la que sume al reino y la idea de entregar a sus hijas como prenda en un juego de naipes, remiten a un soberano despiadado y sin escrúpulos. ${ }^{15}$ Por otro lado, si bien la historia comienza en un palacio que remite a la tradición de los cuentos infantiles, con decoración lujosa, terciopelos, grandes salones con fuentes de comida sobre las mesas, en diversos momentos aparecen elementos que no se corresponden con un tiempo lejano, como pueden ser los jeans ${ }^{16}$ o los brackets.

Resulta necesario aclarar en este punto que, según la propia Meruane en una entrevista concedida al diario Página/12, una de las lecturas que Las infantas posibilita es la de un "correlato fantaseado de las secuelas y las resonancias de la dictadura chilena" (Friera, 2010). En los relatos, como ya se ha mencionado, encontramos diversos indicios que nos remiten a

\footnotetext{
${ }^{13}$ En los nombres de estas dos jóvenes infantas se observa la referencia a Hildegard von Bingen (1098-1179), una abadesa alemana, prolífica escritora, que escribió obras musicales, textos sobre medicina, poesía, así como varias obras teológicas, filosóficas y lingüísticas. A los seis años empezó a tener visiones que continuaron a lo largo de toda su vida. Años más tarde, en torno a 1141, se le pidió que escribiera estas visiones, consideradas de inspiración divina. A mediados del siglo XII, Hildegard fundó el primer convento de monjas autónomo (independiente del monasterio de monjes benedictinos al que antes pertenecía) en Rupertsberg. Realizó varios viajes que le permitieron recorrer diversos lugares y propagar su sabiduría.

${ }^{14}$ Para Sarduy, el espacio urbano barroco es semántico, pero de una semanticidad negativa: "No garantiza al hombre, al recibirlo en la sucesión y la monotonía, una inscripción simbólica, sino que al contrario, dessituándolo, haciéndolo bascular, privándolo de toda referencia a un significante autoritario y único, le señala su ausencia en ese orden que al mismo tiempo despliega como uniformidad la desposesión" (1974: 63).

${ }^{15}$ El padre de las dos infantas encarna la figura del "père-version" de Kristeva (1988: 8), el padre perverso. El soberano, además de entregar a sus hijas, mantiene una relación incestuosa con su hermano Antonio y, como se muestra en el primer cuento, también con su hijo/a; al hilo de esta mención, conviene comentar que, en distintas ocasiones, Greta aparece metamorfoseada en varón: en el cuento "pasos en falso", donde el personaje perseguido se escinde y se vuelve también perseguidor, cuando aparece la asesina de ancianas, y al final, cuando está dormida en un ataúd después de haberse lastimado con una aguja (se describirá su pelo como colorado y muy corto). Por otro lado, volviendo a la figura del padre, en el cuento "reina de piques" se menciona cómo "el tío Antonio, sur de mi padre cuando éste jugaba al norte" (2010: 8) en una posible referencia al cuento "Avatares" de Valenzuela, donde el Señor del Norte es el padre de una tal Nieves, cuya madrastra dialoga con un espejo, y el Señor del Sur queda viudo a cargo de su hija y se casa con "una viuda rabiosa con tres hijas rabiosas", en alusión a Cenicienta.

${ }^{16}$ Hildegreta se viste con unos vaqueros al llegar al bosque, para así ocultar su verdadera identidad. Cuando se ve con esta ropa, menciona que parece un mendigo, en una alusión al cuento tradicional "El príncipe y el mendigo" de Mark Twain, donde, además, puede observarse el tópico barroco del ser y el parecer, muestra de que nada es lo que parece (motivo que subyacerá a lo largo de los relatos de Meruane, desde el momento en el que las dos hermanas deciden mentir acerca de quiénes son, adquiriendo así múltiples identidades).
} 
este contexto histórico, pero si reparamos en la figura del padre y en cómo esta desaparece y es cuestionada en su rol de protector, también podemos pensar en el contexto de la postdictadura, donde, según la propia Meruane, se pone en duda la figura del "gran padre". La lectura que aquí se plantea se centra en la revisión que Las Infantas hace de las diversas tradiciones literarias, pero resulta crucial contextualizar los relatos en ese Chile concreto que a su vez los aleja de la abstracción espacio-temporal de los cuentos clásicos.

En la línea de la revisión de la literatura infantil, conviene señalar que una de las vertientes de los cuentos de hadas tradicionales es la de los dos hermanos. En muchos de los relatos infantiles que corresponden a esta temática, normalmente uno de los hermanos abandona el hogar familiar para vivir una serie de aventuras, mientras el otro permanece en la casa paterna. ${ }^{17} \mathrm{Al}$ cabo de un tiempo, ante los rumores de los incidentes o de la muerte del hermano que huyó, el otro sale a su encuentro. En versiones más modernas, como la de los Hermanos Grimm, ambos hermanos se escapan juntos ante una situación familiar insostenible (por ejemplo, una madrastra malvada). ${ }^{18}$ En la mayoría de los casos, estos hermanos son adolescentes (edad de cambio por excelencia), ya que es el momento que mejor representa el punto de inflexión de una etapa, el umbral entre la infancia y la adultez. Según Bettelheim, el tópico de los dos hermanos es uno de los más antiguos, y su origen puede remontarse a un cuento encontrado en un papiro del año 1250 a.C. Posteriormente se han realizado numerosas versiones sobre este mismo tema, con múltiples variantes. Una de ellas, revisión de revisiones, es la de Meruane, donde la relación entre las dos hermanas ya no se reduce únicamente a lo fraternal, sino que adquiere rasgos sexuales en distintas ocasiones, si bien suelen presentarse casi como algo lúdico, un juego que les pertenece únicamente a ellas dos. En relación a esta idea, convendría mencionar dos aspectos que señala el teórico cubano y que conforman uno de los ejes predominantes del texto de Meruane, como son el placer y, unido a este, el juego. Para Sarduy, la estética del barroco se recrea en lo placentero como modo de enfrentamiento al orden supuestamente normal de las cosas. En concreto habla de una función únicamente placentera del lenguaje, del lenguaje por el lenguaje, sin la finalidad necesaria de la comunicación y la información: "Malgastar, dilapidar, derrochar lenguaje únicamente en función de placer [...] es un atentado al buen sentido, moralista y "natural" [...] en que se basa toda la ideología del consumo y la acumulación" (1974: 99). Concretamente, el barroco se alza como amenaza y ataque a la economía burguesa, parodiándola. El elemento del placer, sin embargo, no se limita al lenguaje y al uso que de este se hace (uso que, además de una función estética, tiene un trasfondo de crítica política), sino que se extiende al cuerpo y a la sexualidad, mostrando sexualidades no reproductivas y que podrían definirse en el caso de Las Infantas como queer. ${ }^{19}$ Unido al placer, por tanto, aparece el erotismo, ambos

\footnotetext{
17 También Valenzuela revisa el tópico de las dos hermanas en su cuento "La densidad de las palabras", siguiendo esta estela tradicional de los hermanos que se separan. Al final del cuento, ambas hermanas terminan por fundirse una en la otra a través del enredo de las joyas y las culebras que las caracterizan. Esta fusión también ocurre en Las Infantas, aunque de manera menos explícita, en el beso final, cuando las hermanas se reencuentran.

${ }^{18}$ El caso de "Hansel y Gretel" no pertenece a esta línea de cuentos, ya que los hermanos no huyen del hogar familiar, sino que son abandonados por sus padres. Sin embargo, las referencias a este cuento en Las Infantas son numerosas, empezando por el nombre de una de ellas, Hildegreta, que pasará a llamarse Greta una vez se separe de su hermana.

${ }_{19}$ Precisamente, Punte (2013a, 2013b) propone una lectura queer de Las Infantas, en la que las sexualidades no hegemónicas ocupan un lugar central y muestran un carácter abyecto y cruel que, ligado a la infancia, aleja el
} 
estrechamente ligados con la idea del juego (y de la obra barroca como tal, frente a la obra clásica considerada como trabajo), que se desliga de su carácter únicamente infantil para adquirir nuevos significados: "Juego, pérdida, desperdicio y placer: es decir, erotismo en tanto que actividad puramente lúdica, que parodia de la función de reproducción, transgresión de lo útil, del diálogo "natural” de los cuerpos" (Sarduy, 1974: 101).

Aparte del motivo de las dos hermanas, Las Infantas revisa varios cuentos tradicionales. Podría decirse que "Caperucita Roja" es el cuento que recorre transversalmente todos los relatos, ya que el personaje de Blanca, aunque su nombre apunte hacia otra princesa, es una versión de la niña de caperuza fijada por Perrault. ${ }^{20}$ Este cuento es uno de los más antiguos; fue recogido por Perrault en el siglo XVII, pero sus orígenes se remontan, según algunos, al mito de Cronos (Saturno en la mitología romana) devorando a sus hijos. En este mito, Cronos se come los hijos que su mujer y hermana Rea va alumbrando, ya que conocía que iba a ser destronado por alguno de ellos, como hizo él con su padre. Zeus, el único hijo que sobrevive gracias a la ayuda de su madre, extraerá del interior de Cronos a los hijos devorados, tal y como sucede en la versión de "Caperucita Roja" de los Hermanos Grimm con la niña y la abuela, deglutidas por el lobo feroz. Por último, en el rastreo que Bettelheim hace de este cuento, menciona una historia de Egberto de Lieja escrita en latín en el año 1023 y titulada Fecunda ratis, donde aparece una niña en compañía de lobos y vestida con prendas rojas.

Para Bettelheim, el rojo es el color que simboliza "las emociones violentas, sobre todo las de tipo sexual" (1977: 243), elemento que adquiere sentido en el cuento tradicional, cuya moraleja explícitamente indica que las jóvenes deben temer al lobo, que a veces es de buena presencia y galán, pero promete cosas que enseguida olvida. El personaje de Blanca encuentra elementos en común con la Caperucita de Luisa Valenzuela en su cuento "Si esto es la vida, yo soy Caperucita Roja", donde el personaje de la niña se desdobla en el de la madre y en el del lobo (construyéndose como una suerte de sujeto trinitario) a lo largo de su recorrido por el bosque hasta la casa de su abuela. El lobo la sorprende en el bosque en distintas ocasiones, y le lanza comentarios aduladores $\mathrm{y}$, a veces, también gestos obscenos: “¿Dónde vas, Caperucita, con esa canastita tan abierta, tan llena de promesas?" (Valenzuela, 1999: 64), invitaciones a las que ella a veces corresponde en relaciones eróticas con el lobo, a quien "a veces cuando duermo sola en medio del bosque siento que anda muy cerca, casi encima, y me transmite escozores nada desagradables" (66). En el caso de Blanca, esta misma relación con el lobo se dará en la pensión en la que ella vive después de que un cazador la recoja en el bosque. ${ }^{21}$ El encuentro erótico entre la niña y el lobo se da en una especie de vigilia: "Soy la

texto de Meruane del imaginario infantil convencional: "Nada más alejado de una visión edulcorada e inocente de la infancia" (Punte, 2013a: 7). En este sentido, el texto se caracteriza como "fuertemente queer" (Punte, 2013b: 298).

${ }^{20}$ El personaje de Hildeblanca, que después pasa a llamarse simplemente Blanca, remite a la clásica Blancanieves, no solo por el nombre, sino también por los enanos que la acompañan en sus fechorías. Sin embargo, Blanca tiene como elemento distintivo una caperuza roja que nos remite a otro cuento tradicional. Esta simbiosis entre dos personajes ya se dio en el cuento "Avatares" de Luisa Valenzuela (cuyo subtexto es "La Cenicienta"): "Somos Blancacienta y Ceninieves, un príncipe vendrá si quiere, el otro volverá si vuelve. Y, si no, se la pierden. Nosotras igual vomitaremos el veneno, pisaremos esta tierra con paso bien calzado y seguro" (1999: 92).

${ }^{21}$ La figura del cazador suele relacionarse tradicionalmente en los cuentos de hadas con el salvador, un hombre bueno que aparece en el momento en el que la protagonista corre peligro. En el caso de Las Infantas, el cazador 
caperucita de tus sueños, que aparece en su minúsculo pijama de niña. Mi traje nocturno silba con la brisa. El aire me levanta los pezones" (Meruane, 2010: 44). Tras una insinuación por parte de la niña (al contrario que en el cuento tradicional y en la versión de Valenzuela, donde es siempre el lobo el que provoca el encuentro), ambos se unen y no faltan elementos que designan cierta agresividad, como son los colmillos del lobo y su aspecto aterrador. Según Kristeva, el goce es lo que da acceso a lo abyecto, pero solo "violentamente y con dolor" (1988: 17). Esta idea se perfila en el relato de Meruane al describir la relación entre la niña y el lobo: "El filo de sus colmillos sabe a almíbar, su gusto me parece arrobado mientras imprime sus patas en mis enormes, exuberantes pechos, y va alzándome hasta la llave que gotea, apenas. ${ }^{22}$ Ay... Déjame, lobo. Pucha... ${ }^{23}$ Le susurro con los ojos cerrados, sudando en esta calurosa noche de primavera" (2010: 45). Por otro lado, ambos personajes, tanto la Caperucita de Valenzuela como Blanca, tienen la caperuza deshilachada por las ramas del bosque y los continuos avatares a los que se enfrentan en ese camino que da paso a la vida adulta. Podría pensarse que la caperuza, de ese color que tanta significación adquiere, es metáfora de aquello que dejó de brillar y de estar intacto, representando así un cuerpo que ya no es infante. Por último, si el cuento tradicional de Caperucita contiene una moraleja que pretende salvaguardar a las niñas de hombres depredadores, el cuento de Valenzuela insinúa la relación sexual entre la niña y el lobo, y el de Meruane muestra explícitamente esa relación y el posterior embarazo de Blanca.

Blanca, en todo momento y de diversas maneras, estará caracterizada por el color rojo. La caperuza aparecerá en los distintos relatos, pero también lo hará una bata de satén rojo con la que está vestida mientras cena con los enanos en la pensión en el cuento "el comedor de la pensión (De cómo Blanca alimenta a los enanos)", en una especie de última cena grotesca en la que se descubrirá la carne humana que están comiendo en el guiso. ${ }^{24}$ Blanca utiliza el batín para seducir a Mario, el enano con mejor olfato, cuando este sospecha que la carne que están comiendo puede ser la del rey derrocado y desaparecido recientemente.

que aparece en el cuento "la espesura del bosque (De cómo Greta encuentra compañía)" es en apariencia bueno, ya que quiere ayudar a Blanca, pero cuando mira su escote ceñido le asoman unos dientes afilados y un "apetito feroz" (2010: 33) de connotaciones sexuales que remiten al lobo como elemento de fuerte carga erótica.

${ }^{22}$ La llave que gotea, el fluido cristalino, el grifo que mana, el lápiz que se entierra con fuerza (todas ellas referencias que aparecen en Las Infantas) hacen alusión explícita a la eyaculación del lobo y muestran el acto sexual en toda su crudeza, algo que no sucede en la versión de Valenzuela, donde únicamente se habla de que Caperucita siente placer cuando se encuentra con el lobo por la noche.

${ }^{23}$ Esta será la palabra que caracterice a Blanca, quien se revela contra el lenguaje correcto que corresponde a dos jóvenes muchachas de la realeza. La revolución, por tanto, empieza ya en el lenguaje. En el cuento "La densidad de las palabras" de Valenzuela, cuyo subtexto es precisamente el cuento tradicional "Las dos hermanas", la hermana que se aleja del palacio por escupir sapos y culebras se asemeja en su lenguaje revolucionario a Blanca; ambas toman el poder a través de la palabra: "las palabras son mías, soy su dueña, las digo sin tapujos, emito todas las que me estaban vedadas; las grito, las esparzo por el bosque porque se alejan de mí saltando o reptando como deben, todas con vida propia" (2010: 82).

${ }^{24}$ Blanca prepara cordero para cenar. Esta imagen puede suscitar dos referencias: por un lado, la religiosa, la del cordero de Dios que quita el pecado del mundo, unida a la idea de los doce discípulos (doce enanos en Las Infantas); por otro lado, la referencia a los cuentos de hadas en los que, ante la petición de una horrible madrastra de comerse a la hija de su marido (como pretende, por ejemplo, en "Blancanieves") e incluso de una suegra de devorar a sus nietos (como en el caso de "La Bella Durmiente" de Perrault), un bondadoso sirviente los ayuda a escapar y sirve, en lugar de carne humana, carne normalmente de cordero o de ciervo. En el caso de la cena de la pensión, se da el juego inverso: en lugar de verdadero cordero, se sirve carne humana (¿la del soberano que anuncian que ha desaparecido?). En cuanto al carácter religioso de algunas escenas, tras esta primera alusión el cuento "grabado sobre lámina" finaliza con un enano rasurado y clavado en un tamiz al sol, en una posible referencia (en este caso subvertida por la parodia) a Cristo crucificado. 
Otro de los elementos principales de este antiguo cuento es el personaje de la abuela. Tradicionalmente, la abuela es una anciana adorable que espera la llegada de su nieta, a quien le ha tejido una caperuza. La niña cruza el bosque con una canasta con dulces para su abuelita, que vive justo en el lado opuesto a la casa materna. En el texto de Valenzuela, el personaje de la abuela se presenta como contrario al de la madre, quien vive del lado conformista de la realidad, mientras aquella se ha arriesgado a salir del bosque, para lo cual ha tenido que cruzar y pasar por los innumerables peligros que este encierra. Caperucita seguirá este ejemplo, hasta fundirse con su abuela: "Y por fin somos una. Calentita" (Valenzuela, 1999: 70). Pero esta abuela da todavía un giro más, que también podrá observarse en Meruane, aunque de manera mucho más sutil e implícita. Así como la Caperucita de Valenzuela es niña, madre y lobo a la vez, hacia el final del relato es también abuela, por lo que la anciana se convierte a su vez en lobo: "La reconozco, lo reconozco, me reconozco" (1999: 70). En el cuento "la ratonera" de Meruane, tenemos una nueva versión de esta abuela, que sigue la estela de Valenzuela. En este caso, nos encontramos en un departamento a medianoche, donde vive sola una anciana. De repente, siente que ha llegado la tan temida asesina de ancianos, una joven de voz infantil y pelo corto (¿Greta?) que asesina con veneno para ratas. La anciana desea ablandar a la joven, queriendo regresar a la antigua idea de la relación idílica entre nieta y abuela que representa el cuento "Caperucita Roja": "Quizá todo sería distinto si en vez de ser tan dura, tan cortante, se dejara el pelo largo y sonriera y viniera a traerme comida fresca en un canasto, si me llamara abuelita y se acurrucara entre mis brazos" (2010: 79). ${ }^{25}$ Pero esta abuela es, en realidad, en ese juego barroco del ser y el parecer, un lobo cuyo deseo es devorar (como metáfora sexual, al igual que en el cuento tradicional) a la joven asesina, para lo cual le tiende una trampa: le invita a comer unas pastillas de color verde y rojo que la sumen en un largo sueño. Una vez dormida la joven, la anciana siente una "energía voraz cuando me acerco a ella y la huelo por todos lados, no puedo controlar mi deseo, comprendo entonces que la muchachita que tengo ante mí es el peor de todos los posibles venenos" (2010: 83). Esta anciana-lobo podría relacionarse también con la figura de la bruja, al igual que sucede con la señora que regenta la pensión donde Blanca reside y a quien ésta asesina por el ruido que hace por las noches al roncar. La primera de ellas deja aflorar su instinto sexual, mientras que la segunda tiene instintos antropófagos (mata personas para comerlas después). Ambas muestran un "retorno de lo reprimido" (Punte, 2013b: 297) característico del personaje de la bruja, ser marginado por considerarse ajeno a la norma convencional y hegemónica.

Por último, no podemos dejar de mencionar el bosque como espacio principal en el que se desarrolla la trama de "Caperucita Roja" y que es un elemento siempre presente en los cuentos de hadas. El bosque es un lugar mágico, encantado, lugar de transformaciones. Para Bettelheim, el bosque es "el lugar donde se debe afrontar y vencer la oscuridad; donde se resuelven las dudas acerca de lo que uno es; y donde uno empieza a comprender lo que quiere ser" (1977: 133). También es el lugar relacionado con el inconsciente, por ser un espacio oscuro y casi impenetrable. Más allá de esta mirada, Punte señala, en relación a Las Infantas y a otras ficciones modernas, que el bosque "exhibe una estructura de pliegue, que aúna las

\footnotetext{
${ }^{25}$ Para remarcar la relación con el cuento tradicional, esta joven asesina de ancianos extraerá del armario un chaleco rojo, viejo y raído.
} 
nociones de altura y abismo, de profundidad, de permanente oposición entre fondo y forma. No se ve todo lo que circula en él; esconde más de lo que muestra" (2013b: 300). En este sentido, el bosque empieza a adquirir connotaciones más negativas, relacionadas con lo abyecto. Y, siguiendo la línea de Kristeva, los abyecto sería "aquello que perturba una identidad, un sistema, un orden. Aquello que no respeta los límites, los lugares, las reglas" (1988: 11). En este marco se moverán los personajes de Las Infantas, sobre todo, las dos hermanas. El bosque, como espacio de lo abyecto, vuelve abyectos a los sujetos que lo penetran y habitan.

Conviene mencionar que en los relatos de Meruane es constante la alusión a un olor a tierra y a humedad, que no solo remite al bosque, sino que también hace referencia, a veces no de manera tan velada, a lo sexual. En el momento en el que ambas hermanas se separan en el bosque y prometen no desvelar su identidad, intercambian su ropa interior como vínculo que las unirá a partir de entonces; ya desde este momento perciben que huele a tierra. Y este será el olor que en el futuro irán sintiendo cada vez que se encuentren, sin saberlo, una cerca de la otra. También la Caperucita de Valenzuela, al hacer referencia a los recovecos oscuros del bosque, alude al musgo y a la humedad. Punte habla del bosque, siguiendo esta línea, como "máquina deseante" (2013b: 300), espacio en el que los sentidos establecidos se derrumban. Por su parte, Kristeva afirma que lo abyecto únicamente será accesible a través del placer y del goce; el espacio del bosque permitirá ese acceso, convirtiéndose en lugar de encuentros que desafían la norma y que establecen interacciones sexuales no hegemónicas ni heteronormativas, como el incesto o la homosexualidad.

Pero este bosque, a su vez, unido a las alusiones al cordón umbilical que en él hacen las infantas, nos lleva a pensar en el nuevo hogar de las dos hermanas. Indicio de esto son los sueños que Greta tiene cuando duerme en el bosque, rememorando su casa, "reviviendo recuerdos de protección" (Bachelard, 2000: 29). Según Bachelard, el espacio de la casa se relaciona con lo materno, con la cuna, el lugar del que provenimos. En el caso de Las Infantas, abundan los cordones, esos "lazos antropocósmicos" (Bachelard, 2000: 28), pero la figura materna desaparece. La casa, lejos de ser el lugar de protección, es el lugar del peligro, encarnado en la figura paterna. Ante esta situación, el nuevo hogar de las dos hermanas es el bosque, espacio de límites porosos, de constante tensión entre lo de adentro (la casa, el hogar) y lo de afuera (el camino, la vida y, en este caso, también la ciudad).

Por otro lado, el bosque es el espacio de la ensoñación y, por tanto, también el de la libertad. Del mismo modo, según Bachelard, el sueño, la imaginación, son indisociables de la memoria. En este sentido, el bosque actúa también como espacio del recuerdo, donde la infancia primera perdura en la memoria, en los sueños que este lugar provoca: "En el sueño del niño, la imagen prevalece sobre todo [...]. La ensoñación hacia la infancia nos entrega a la belleza de las imágenes primeras" (2004: 155). En Las Infantas, Blanca y Greta se reconocerán tal y como son únicamente en el bosque, ya que, cuando lo abandonan, se metamorfosean en distintos personajes que no recuerdan quiénes son ni de dónde vienen. El bosque funciona así como casa, espacio de la infancia primera, hábitat de la memoria que proporciona un anclaje, un origen y que, de alguna manera, viene a sustituir la ausencia materna.

Aunque en el caso de "Caperucita Roja" tenga un papel principal, el bosque está presente igualmente en la mayoría de los cuentos de hadas. Y son varios los que Meruane 
revisa en Las Infantas. "Hansel y Gretel", por ejemplo, tiene un carácter transversal en los relatos, ya que el nombre de Greta remite directamente a este cuento. En "la espesura del bosque (De cómo Greta encuentra compañia)" se narra el encuentro de la niña con un híbrido entre perro (se deduce únicamente por el ladrido) y hombre, ${ }^{26}$ que aúlla pidiendo que alguien le corte el cordón umbilical. Greta se lo cortará y lo amarrará a su muñeca para que el animal no escape. Le da el nombre de Hansel (Hans, a partir de ese momento) y este deja de ser una bestia, en una especie de acto performativo y sanador de la palabra. A partir de entonces, Greta y Hans recorrerán juntos la ciudad y en determinado momento ella quedará embarazada y dará a luz una muñeca. De este modo, la alusión a los hermanos del cuento tradicional queda subvertida por la posibilidad de una relación incestuosa entre ambos.

Además de los relatos tradicionales mencionados, Las Infantas tiene también como subtextos los cuentos "Barbazul", "La Bella Durmiente", "El flautista de Hamelin" (en un momento se menciona a un tal Homelin), "La Cenicienta" o "Pinocchio". Los tres últimos aparecen a través de detalles concretos como las ratas, la Cenicienta despotricando contra sus hermanas en una fiesta o la muñeca de madera que mira a su creador desde la estantería y cobra vida. En el caso del personaje de Barbazul, este emerge en dos ocasiones. Por un lado, en el cuento "departamento urbano (De cómo se enfiestan en la ciudad)", cuando Hans aparece en la fiesta con un hacha ensangrentada; al tratarse de una fiesta de disfraces, queda la duda de si protagoniza a una suerte de Barbazul o si de verdad ha participado en el asesinato de la dueña de la pensión. Por otro lado, la versión de este cuento aparece de manera más explícita en "cuencas vacías", cuando una de las hermanas descubre el cadáver de la madre bajo la alfombra del living, donde el padre la tenía escondida desde su muerte.

Por su parte, "La Bella Durmiente" emerge en el cuento "el tribunal (Del trance que implica un juramento)", cuando Greta es llamada a declarar en el juicio contra Blanca. Mientras declara, sin dar ningún dato acerca del suceso, Greta está tejiendo y, al pincharse con la aguja, cae dormida en un profundo sueño en el que la acompañan todos los presentes. Por último, en el cuento "templo puertas adentro (De cómo se produce el gozoso reencuentro)" Greta duerme en un ataúd en el altar de una iglesia (el templo principal de la ciudad), y Blanca aparece como si fuera el príncipe que tiene que despertarla. La llama "Greta la durmiente" (2010: 143) y se menciona cómo han estado cien años separadas, al igual que en el cuento original. En lugar del tradicional beso, lo que despierta a Greta es el olor a tierra de la ropa interior de Blanca; pero, lejos del despertar mágico de los cuentos de hadas, Greta se golpea contra el vidrio del ataúd, tiene la voz ronca y bosteza "como plebeya" (2010: 144). Ante el espectáculo erótico que protagonizan ambas hermanas, aparece el sacerdote con la Biblia y las insta a confesarse y a pedir perdón por sus pecados. Mientras lo hacen, entre besos y caricias, Greta asfixiará al sacerdote (al que ambas llaman padre, en una referencia ambigua al cura, a su padre el soberano y a Dios). Algo similar a esta asfixia ocurre en "No se detiene el progreso" de Valenzuela (cuyo subtexto es igualmente "La Bella Durmiente"), en el momento en el que los amantes se unen: "la ama con pasión creciente mientras ella se sumerge cada vez en sueños más profundos donde cabalga víboras y la sangre se le hace clorofila y todo su cuerpo ruge como rugen las ranas a merced de tormentas. La ama mientras

\footnotetext{
${ }^{26}$ Más tarde, en el cuento "el tribunal (Del trance que implica un juramento)", el juez anunciará que se ha descubierto el asesinato de un "hombre perruno" (2010: 130), delito cometido por Greta pero del cual no se la acusa.
} 
de sus gráciles brazos van creciendo poco a poco unos zarcillos viscosos que lo atrapan" (1999: 75).

\subsection{Entre Pigmalión y el romance de La Manekine}

El cuento "hermanastras" de Las Infantas puede tener como subtexto a Las aventuras de Pinocchio, escrito por Carlo Collodi entre 1882 y 1883. La historia narra las peripecias de un títere de madera fabricado por Geppetto, que cobra vida y vive una serie de aventuras. Como ocurre con la mayoría de los cuentos infantiles, el original disiente en algunos aspectos de las versiones popularizadas posteriormente, sobre todo en la crueldad de determinados actos o escenas.

El cuento de Meruane está narrado desde el punto de vista de una muñeca de madera que observa a su creador en el taller donde este está tallando muñecas en serie. ${ }^{27}$ Ella, de nombre Manekine, es especial, ya que fue la primera obra del artesano, su hija primogénita, "la matriz original" (2010: 64). Un buen día entra al taller Mané (diminutivo de Manekine, una especie de doppelgänger), una niña que tiene curiosidad por aquella muñeca que no es exactamente igual a las demás.

En el mito clásico, Pigmalión crea una escultura de mujer que aúna los rasgos perfectos para lograr una belleza ideal. Al terminar, queda perdidamente enamorado de su propia creación y pide a los dioses que le den vida. Venus le concede este deseo y Galatea se convierte así en una mujer real, igualmente enamorada de su creador. En el cuento de Meruane, Manekine está enamorada del artesano que la talló y celosa de la relación amorosa de este con la niña (¿ella misma, desdoblada?). En este sentido, el cuento de Meruane parece seguir más estrechamente la línea del mito griego que la historia de Collodi.

Por su parte, el nombre de la muñeca nos remite a un romance francés del siglo XIII, titulado precisamente La Manekine. En el siglo XIV surge un tipo de drama religioso que cobra gran popularidad en Francia: el miracle par personnages, cuyo tema principal son las leyendas sobre la Virgen María. El objetivo de estas obras teatrales es educar al pueblo, principalmente a través de representaciones que muestran la intercesión de la Virgen en favor de aquellos que se habían desviado del camino correcto o que estaban afligidos, pero eran inocentes. Según Carol Harvey, la principal fuente de conocimiento de estos dramas religiosos se encuentra en los dos volúmenes que comprenden el manuscrito Cangé, editado en 1966 bajo el título de Les miracles de Nostre-Dame par personnages, un importante registro donde encontramos cuarenta milagros compuestos y representados en París entre 1339 y 1382.

Estos dramas suelen tomar a sus personajes de narraciones ya existentes como las hagiografías o las historias épicas con héroes como protagonistas; también de fuentes históricas, libros de caballería o cuentos pertenecientes al folklore. Dentro de estos milagros, el tema de la doncella injustamente perseguida es bastante recurrente, y aparece en el milagro La fille du roy de Hongrie (1371), inspirado, según asevera Harvey, en el romance en verso La Manekine (1230) de Phillipe de Remy, considerado la primera inscripción en lengua

\footnotetext{
${ }^{27}$ La imagen de una muñeca singular rodeada por otras que son idénticas entre sí y que responden a un proceso de fabricación seriado recuerda a Wakolda (2011), de Lucía Puenzo, donde la muñeca del mismo nombre es auténtica, propia, mientras que las que el papá de Lilith fabrica responden a una demanda comercial que las obliga a ser iguales.
} 
vernácula del cuento arquetípico "La doncella sin manos", que posteriormente Perrault fijaría como "Pellejo de asno" (donde se mantiene el motivo original y principal de la huida pero no las manos cortadas) y los Hermanos Grimm como "La doncella sin manos" (donde se mantiene el tema de la mano cortada pero se suprime la maldad de la madre del rey), todas ellas historias de iniciación. En relación a La Manekine, Harvey señala que "a pesar de que muchos de sus temas y motivos son corteses, los elementos que aluden al incesto y a la automutilación, a la injusticia y a los celos, pertenecen al lado más oscuro del folclore" (2002: 110). ${ }^{28}$ Estos elementos lóbregos parecen ir acercándonos al mundo que Meruane recrea.

Phillipe de Remy narra la historia de Joïe, joven devota e hija del rey de Hungría cuya madre, al morir, hizo prometer a su esposo que solamente se casaría con una mujer que la igualara en belleza. Después de buscar y no encontrar, el rey se dio cuenta de que la única mujer igual de bella que su esposa era su hija. Queriendo cumplir con la promesa, por tanto, le pide matrimonio. Joïe se horroriza ante la idea de un matrimonio incestuoso y se corta la mano izquierda, provocando así la ira de su padre, quien la manda quemar en la hoguera. El cuento de Meruane contiene al menos dos elementos procedentes de esta historia. Por un lado, la muñeca se comporta como hija del creador, su padre, pero, en este caso, es ella la que busca una relación incestuosa con él. Al contrario que en el romance francés, en el caso del cuento "hermanastras" dicha relación llega a consumarse. Por otro lado, la constante mención al fuego en el romance francés también aparece en el cuento que integra Las Infantas, cuando la muñeca, ante un ataque de celos, provoca un incendio y quema a su creador, a la amante y a ella misma.

Retomando el romance francés, Joïe se libra de la hoguera gracias a la ayuda de un sirviente (motivo recurrente en muchos cuentos clásicos), quien la sube a un bote sin vela ni timón y la deja en el mar a la deriva, a merced de las olas y del temporal. Gracias a los rezos que le dirige a la virgen, llega sana y salva a las orillas de Escocia, donde decide esconder su identidad (recordemos la promesa que se hacen las dos infantas en el momento en el que se separan en el bosque) y hacerse llamar Manekine, que significa 'muchacha que no tiene mano'. El joven rey de Escocia se enamora de ella y contraen matrimonio, provocando así los celos de la madre de aquel (otro motivo de gran presencia en los cuentos de hadas), que una vez más manda quemar viva a su nuera y al bebé que acaba de nacer. Por segunda vez, un criado la salva y la sube al mismo bote, dejándola otra vez a la deriva. Esta vez, sus rezos y la ayuda de la Virgen la llevan hasta Roma, donde es rescatada por un senador. Transcurridos siete años, llega a la ciudad el rey de Escocia, que ha pasado largo tiempo buscando a su mujer y a su hijo, y también lo hace el rey de Hungría, arrepentido por el arranque de locura que tuvo años atrás. El final del romance es feliz, pues el Papa le repone a Joïe la mano que le faltaba y que había estado guardada en el interior de un esturión, y el rey de Escocia pasa a ser también rey de Hungría y de Armenia.

Si bien la historia de Meruane difiere en gran medida de la de Remy, puede verse un sustrato de La Manekine francesa en el cuento "hermanastras", imbricado con el mito de Pigmalión y con el personaje de Pinocchio. Una gran diferencia con respecto al romance es que la Manekine de Meruane sí tiene manos pero, sin embargo, en un terremoto pierde uno de

\footnotetext{
28 "yet although many of its themes and motifs are courtly, the elements of incest and self-mutilation, injustice and jealousy belong to the darker world of folklore" (la traducción es la nuestra).
} 
los ojos al caer de la estantería, y su mirada ya no vuelve a ser la misma. Sin embargo, en el cuento "cajita para la bailarina" se mencionará explícitamente a una muñeca sin dedos con la que la maestra sueña.

\subsection{El mito del Minotauro y el intertexto borgiano}

Son varios los elementos que nos hacen pensar en el mito del Minotauro como subtexto que atraviesa los relatos de Meruane de principio a fin. Desde el epígrafe se hace referencia al cordón umbilical como cicatriz primera, idea que aparecerá en sucesivas ocasiones y que remite al hilo de Ariadna, aquel que la hija de Minos entregó al joven y valiente Teseo para adentrarse en el laberinto construido por Dédalo y matar al Minotauro. También la ciudad de Santiago, con sus innumerables cruces de "laberíntica espesura" (2010: 141) remite al mito griego, al igual que la propia construcción de Las Infantas, con relatos entrecruzados, los unos conduciendo a los otros pero desorientándonos cada vez por nuevos pasadizos de sentido.

El mito nos presenta a Minos, rey de Creta, cuya mujer Pasifae da a luz un hombre con cabeza de toro, fruto de la relación de esta con un gran toro blanco que Poseidón regala a su marido. El Minotauro es encerrado en el laberinto diseñado por Dédalo, de donde no puede salir y adonde, cada nueve años, llevan a siete varones y siete doncellas a ser sacrificados para alimentarlo. El número nueve tendrá gran presencia en Las Infantas, ya que serán nueve las vueltas que Greta le de al cordón para asfixiar a Hans, y nueve las veces que las dos hermanas deban repetir la oración que las absuelva. A su vez, el título del último relato remite al mismo número ("nueve nudos en el palace") y en él se narra un sueño en el que aparecen nueve hombres cada nueve años, trayendo la luz del sol en sus pupilas, diciendo nueve mentiras; y, al fin, "la espera alcanza su hora nona" (2010: 148). ${ }^{29}$ En el último relato de Las Infantas, la madre del supuesto Minotauro tratará de asfixiar a Ascarión dándole nueve vueltas al cordón umbilical alrededor de su cuello; después, con el mismo cordón umbilical, se ahogará a sí misma. Al final del relato esta escena se repetirá, con el Minotauro convertido en su madre y asfixiando al anciano, convertido en Ascarión, en un eterno juego metamórfico. Las constantes transformaciones de los personajes de Las Infantas remiten a una nueva concepción del sujeto, descentrado, que Sarduy señala como característico de la estética barroca. Un sujeto que no está donde se lo espera, "en el sitio donde un Yo gobierna visiblemente el discurso que se enuncia" (Sarduy, 1974: 77), sino que la concepción unitaria y fija de sujeto se escinde y da lugar al surgimiento de una nueva mirada que, al igual que la ciudad barroca, abierta e ilimitada, posibilita múltiples devenires. ${ }^{30}$

El relato de Meruane no es solamente una revisión del mito del Minotauro, sino una especie de meta-revisión, ya que retoma la lectura que Borges hizo sobre el mito en su cuento "La casa de Asterión", para darle una vuelta de tuerca. En el cuento, un yo, que puede ser el Minotauro, o el hijo del Minotauro, pero que posteriormente pasa a ser Pasifae o Ariadna, vive en un alcázar en ruinas, en un palacio donde hay cadáveres y una alfombra

\footnotetext{
${ }^{29}$ En "La casa de Asterión" de Borges, el número que aparece en varias ocasiones es el catorce, identificado en boca del Minotauro con el número infinito. De este modo, el número nueve en Las Infantas puede ser resignificado del mismo modo.

${ }^{30}$ En futuros trabajos se abordará la cuestión de la construcción del sujeto en Las Infantas, que responde a la filosofía del devenir y del sujeto nómada de Deleuze, que posteriomente Braidotti revisa en los términos de devenir mujer/animal/insecto, aplicable a los personajes presentados en los cuentos de Meruane.
} 
ensangrentada. ${ }^{31}$ También en Borges, "los cadáveres ayudan a distinguir una galería de las otras" (2016: 86). Este palace contiene numerosas galerías de "retorcidos corredores" (Meruane, 2010: 148) y vericuetos que remiten al legendario laberinto de Creta. En estas ruinas (punto de partida de la creación barroca según Sarduy) que parecen aludir también a "Las ruinas circulares" de Borges, nuevos "senderos se bifurcan" (Meruane, 2010: 148), multiplicando así los espacios en una nueva referencia al autor argentino. Pero las alusiones no son solamente indirectas o implícitas, sino que se explicitan con la aparición de un anciano sabio y ciego (¿el propio Borges?) cuyos pasos y bastón de caoba resuenan sobre el empedrado. Sus primeras palabras serán "Sé que me acusan de soberbia" (2010: 149), la oración con la que se inicia el cuento borgiano. De este modo, el texto de Borges ya no es únicamente subtexto, como ocurría con los cuentos tradicionales, sino también intertexto. En este sentido, el anciano encarna la figura del redentor presente en el cuento de Borges y al que Asterión espera con impaciencia (hecho al que el relato de Meruane también hace referencia), y también al hombre que deberá descifrar el enigma que acompaña a la imagen de Ascarión. En ambos cuentos, la espera del redentor genera angustia, ya que es una suerte de salvador que nunca parece llegar o que, al llegar, no es lo que se espera: “¿Cómo será mi redentor?, me pregunto. ¿Será un toro o un hombre? ¿Será tal vez un toro con cara de hombre? ¿O será como yo?" (Borges, 2016: 87). En el cuento de Meruane, este redentor que en el cuento borgiano es una incógnita y que se resuelve en la figura de Teseo, será el mismo Borges, perdido en sus propios laberintos, el anciano ciego y sabio que llega con la historia del origen del narrador, el enigma que debe ser descifrado.

Este anciano comienza a narrar la historia de un tal Ascarión (distorsión evidente de Asterión), cuyo rostro aparece en un libro ilustrado, a cambio de ganarse su libertad y salir del laberinto. ${ }^{32}$ Según cuenta el anciano, Ascarión era el padre del narrador y vivía en un laberinto. Su mujer quiso vengarse de él por haber engendrado en ella a un monstruo, y para ello le dio un cordón umbilical a un "hombre traicionero" (2010: 149) que se dispuso a matarlo. ${ }^{33}$ Pero no lo logró, ya que la voz dulce de Ascarión lo enterneció. De este modo, la madre tira enfurecida del cordón umbilical hasta desgarrarlo y llega a su marido, a quien da de mamar como a un hijo y lo duerme en su regazo, para asfixiarlo después con el cordón y asfixiarse a sí misma. Pero Ascarión no muere (¿aparece metamorfoseado en el anciano?). Esta historia, narrada por el ciego, no parece convencer al narrador, quien lo desnuda y le

\footnotetext{
${ }^{31}$ Al inicio del relato, el narrador hace referencia a los sueños en la clave que apunta Bachelard y que hemos mencionado en relación a las ensoñaciones de Greta: "Cumplo un olvido sin sentencia, todo intento por imaginar algún origen, monárquico, quizá cíclico y remoto, se apacigua con el poder proveniente de los sueños” (2010: 146). El sueño funciona como espacio que permite rescatar la infancia y lo materno, el origen. La imaginación que posibilita el sueño se torna, como hemos dicho ya, indisociable de la memoria que, en este caso, el narrador quiere reconstruir.

${ }^{32}$ El narrador descubre el rostro de su padre, Ascarión, en este libro. Pero no consigue descifrar las letras que acompañan a la imagen. En el texto de Borges, Asterión tampoco sabe leer: "El hecho es que soy único. No me interesa lo que un hombre pueda transmitir a otros hombres; como el filósofo, pienso que nada es comunicable por el arte de la escritura. Las enojosas y triviales minucias no tienen cabida en mi espíritu, que está capacitado para lo grande; jamás he retenido la diferencia entre una letra y otra. Cierta impaciencia generosa no ha consentido que yo aprendiera a leer. A veces lo deploro, porque las noches y los días son largos" (2016: 84-85).

${ }^{33}$ Resulta ambigua la identidad de la madre, ya que, si es la que da el cordón al hombre traidor (Teseo), se trata de Ariadna. Pero en el mito original, así como en la versión de Borges, Ariadna es la hermanastra del Minotauro. Por otro lado, la madre del narrador puede ser Pasifae, y así, en esta nueva versión del mito, ser ella quien quiere matar a su propio marido que, a diferencia del mito original, es ya un Minotauro.
} 
ofrece su pecho multiplicado sobre la cama que un día fue de su padre. Mientras el ciego bebe su leche, reproduciendo la escena del pasado, el narrador, convertido ahora en su propia madre, comienza a enrollar el cordón alrededor del cuello del anciano que, a su vez, empieza a adquirir un aspecto taurino y termina por volverse Ascarión.

Este final parece volver al inicio, a la historia del padre que ahora es la del hijo, en un tiempo cíclico, premoderno, que nos remite a la idea del eterno retorno ya mencionado como muestra de la imposibilidad de salir del laberinto y del enredo textual que es, igualmente, Las Infantas. El tiempo circular, la repetición incesante estructura la novela de Meruane, instalando al final del libro una vuelta al inicio, una mímesis de la historia que se narra como historia pasada pero cuyos sucesos van a volver a acontecer. La historia, por tanto, volverá a repetirse, sin posibilidad de salir de un tiempo que se torna a su vez laberíntico, atrapante. En este sentido, la estructura narrativa del texto, como dicta la estética barroca, lleva a pensar en cierta fusión forma-fondo.

El desdoblamiento del padre en el hijo, del ciego en el padre, del hijo en la madre y la esposa, en un infinito juego de dobles se dibuja ya en el cuento de Borges, cuando Asterión habla de que el juego que más le gusta es "el de otro Asterión" (2016: 85), elemento clave también en Las Infantas, donde, de manera lúdica, barroca al fin, las hermanas se multiplican o escinden en numerosos personajes en pos de ocultar su identidad; incluso, en ocasiones, parecen ser una sola que se desdobla primero en dos (como en el caso del otro Asterión) y después se multiplica y se disemina por diversas historias, formando un laberinto.

\subsection{El Bildungsroman y los libros de caballería}

Por último, cabe mencionar brevemente que Las infantas contiene elementos propios de los libros de caballerías y de las novelas de aprendizaje que comprenden la tradición del Bildungsroman. Noguerol observa la estructura propia de este tipo de novelas en los Cuentos de Hades de Valenzuela, y esta misma observación es aplicable al caso de los cuentos de Meruane: "La estructura del bildungsroman, que desarrolla el proceso de maduración de las protagonistas desde una inicial ingenuidad hasta que adquieren conciencia sobre su destino, se perfila como recurrente en los diferentes relatos" (2006: 393). Sin embargo, los relatos de Meruane parecen subvertir igualmente esta línea, ya que no existe tal ingenuidad inicial propia de la infancia, sino que, desde un principio, estas infantas son perversas, muestran el lado oscuro y abyecto de la infancia. Del mismo modo, el camino que deben recorrer y que es metáfora de la vida en las novelas iniciáticas y de aprendizaje (aquí representado por el bosque y el espacio de la corrupción que es la ciudad) no las lleva a un estadio moral y espiritual superior, a una conciencia de quiénes son, ya que a lo largo del camino cometen varios crímenes que toman como juegos (lo infantil siempre subyace, aunque perverso). Por otro lado, la conciencia sobre el ser que otorga la enseñanza del Bildungsroman no llega a alcanzarse por el constante juego especular de los dobles y de las identidades fragmentadas de ambas hermanas. Así, estas continuas metamorfosis actúan, según Punte, como "sistema de espejos enfrentados, que no permite al lector poner el pie ni en uno ni en otro" (2013b: 299).

Asimismo, Las Infantas se nutre de los libros de caballerías, relación que también señala Punte (2013b). Estas ficciones, popularizadas en Europa sobre todo en el siglo XVI, presentan las aventuras de caballeros andantes, héroes que, apartados del mundo, llevan a cabo sus proezas en solitario. La finalidad de estas novelas es la ejemplaridad, el didactismo 
$\mathrm{y}$, bajo la premisa del delectare et prodesse, también el divertimento. A su vez, estas historias contienen elementos propios del amor cortés, noble, caballeresco, al igual que sus protagonistas, héroes que honrarán su linaje en cada hazaña, siempre en un marco fantástico, a veces inverosímil. Pero en este tipo de novelas no solo tenemos un único protagonista, sino que en ocasiones proliferan varios personajes que dan lugar a distintas tramas argumentales que se entrecruzan, como ocurre en los cuentos de Meruane.

Las Infantas, una vez más, toma elementos que caracterizan a la tradición y les imprime una visión descentrada, subvierte al héroe caballero convirtiéndolo en dos niñas perversas que llevan a cabo varios crímenes; por tanto, las proezas ya no son tales, sino que adquieren un tinte oscuro. Por su parte, el amor está lejos de lo cortés, a pesar de la supuesta sangre azul de las infantas, y se torna abyecto, violento, crudo, lo cual, entre otras cosas, no permite cumplir con el precepto del didactismo propio no solo de los libros de caballerías, sino también de la literatura infantil. El carácter fantástico del universo de los caballeros andantes envuelve también los relatos de las dos hermanas, pero siempre desde el lado de las sombras y sin desligarse completamente del anclaje en el mundo real, un mundo en ruinas, elemento fundamental de la estética barroca tal y como se ha visto en varias ocasiones a lo largo de este trabajo.

\section{Conclusiones}

Las Infantas se nos presenta como un compendio de tradiciones clásicas occidentales revisadas desde el margen crítico que según Sarduy es Latinoamérica. Los aspectos de la estética barroca mencionados a lo largo de este trabajo describen la línea trabajada por Meruane en esta recopilación de relatos $\mathrm{y}$, por su carácter crítico y desestabilizador, configuran lo que Sarduy denomina neobarroco, entendido, como ya se ha dicho, como un paso más, una revolución, un "reflejo estructural de un deseo que no puede alcanzar su objeto" (Sarduy, 1974: 103). Tal sería un modo posible de describir Las Infantas, como la persecución de lo inalcanzable, de una hermana que no consigue encontrar a la otra (que, en un punto, es ella misma), de un otro que el yo no alcanza a ver como propio, de un deseo frustrado por la imposibilidad de llevarse a cabo.

El texto, subversivo tanto en la forma como en el contenido, constituye a través de la hibridez un laberinto no solo textual sino también metafórico, en el cual los personajes se encuentran atrapados. Este laberinto, que también se manifiesta en el espacio de la urbe, en este caso en la ciudad de Santiago de Chile, es a su vez representación de una realidad que se torna opresiva y angustiante. Retomando a Borges, "la casa es del tamaño del mundo; mejor dicho, es el mundo" (2016: 86). El bosque y la ciudad se convierten en nuevos hogares, laberínticos en sí y metáforas de la realidad. Por tanto, el espacio por excelencia de los cuentos infantiles se combina con el espacio barroco y a su vez posmoderno de la ciudad, ambos convertidos en lugares de corrupción y abyección.

Los personajes clásicos son puestos en un mundo en ruinas (el residuo como núcleo barroco de la creación) donde las hazañas ya no son heroicas, sino que hacen de ellos antihéroes, anti-princesas, anti-príncipes, siempre en un borde liminal entre lo humano y lo animal, entre lo uno y lo otro, que da lugar a una serie de juegos especulares y de dobles que hacen tambalear la visión unitaria y las verdades unívocas. El texto muestra así su potencia 
crítica, su capacidad de subvertir la norma a distintos niveles, a través de la mezcla y de la estética elíptica del descentramiento.

El hecho de revisar bajo una óptica desestabilizante los cuentos tradicionales permite a Meruane volver a la tradición cuestionando los discursos establecidos en torno a la infancia. De este modo, se construye un nuevo relato alternativo, donde sale a la luz el lado más oscuro de las ficciones infantiles, lejos de la edulcoración propia de las versiones que han perdurado en Occidente. Esta revelación del margen, de lo abyecto, se corresponde con el margen del que se emite el discurso, ese margen en ruinas que es el Chile de la dictadura. La infancia, en ese contexto, no puede corresponderse con los finales felices de los cuentos de hadas tradicionales.

Según Ezequiel Acuña, "Meruane pone en crisis el relato aleccionador y por lo tanto el pasaje de la infancia a la adultez como una forma de civilidad" (2010). De este modo, la concepción occidental de la infancia se pone en cuestión y se muestran nuevos devenires, nuevos sujetos infantes que representan lo abyecto, el margen constituyente de toda norma. Los personajes clásicos, arquetípicos, adquieren una identidad concreta y materializan valores específicos, lejos de las moralejas tradicionales propias de la literatura infantil. Así, se generan nuevas enseñanzas que deconstruyen lo moral y se regodean en lo grotesco, en lo divergente. Tal y como indica la cita con la que se abre este trabajo, "trato de narrar la otra cara de una historia de escisiones que a mí me difama" (Valenzuela, 1999: 83), en la narración de Meruane emerge el lado oculto del espacio de la infancia.

Esta narración constituye un desafío literario, un desafío de la escritura y de la forma, donde la rebelión comienza ya en el lenguaje, para dar lugar a lo que Daniel Noemi Voionmaa llama una "escritura de resistencia", donde, partiendo de la noción de escritura de Barthes, "la escritura deviene el vehículo para dar a conocer la historia (y la historia del presente debiéramos añadir); en su forma conecta creación y sociedad forjando de ese modo la posibilidad de una instancia solidaria. Escritura que, por tanto, reconoce en sí misma la presencia del otro sin negarle su radical e inefable diferencia" (2012).

Las Infantas, a través de la revisión de los cuentos clásicos, construye una escritura del otro en un tejido barroco y, más concretamente, neobarroco, que toma como punto de partida el juego y el placer, elementos que vertebrarán todos los relatos y que están estrechamente ligados con el universo infantil. Pero, en ese afán crítico que también es núcleo de lo barroco, el juego ya no es cosa de niños que experimentan en el paso a la vida adulta, sino perversión, pérdida de referentes y paradigmas legítimos. Pérdida de la madre, del padre, de la idea de nación como hogar (la crisis de la escisión, de la separación, a la que se hace alusión en la cita de Sarduy que abre Las Infantas, así como en la de Valenzuela al inicio de este trabajo). Ante este abandono, que es también el abandono de Chile por parte de un "gran padre", las dos infantas llevan a cabo un recorrido vital, un viaje igualmente barroco al submundo de los instintos no reprimidos ni sujetos a la moralidad clásica y a la imagen de castidad, inocencia y pureza propia de la infancia. 


\section{Bibliografía}

ACUÑA, Ezequiel: "Juguemos en el bosque". Página/12, el 20 de junio de 2010: https://www.pagina12.com.ar/diario/suplementos/libros/10-3880-2010-06-20.html (última consulta: 25/10/2017).

BACHELARD, Gaston (2000): La poética del espacio. Buenos Aires, Fondo de Cultura Económica.

--- (2004): La poética de la ensoñación. México, Fondo de Cultura Económica.

BETTELHEIM, Bruno (1977): Psicoanálisis de los cuentos de hadas. Barcelona, Editorial Crítica.

BORGES, Jorge Luis (2016): El Aleph. Buenos Aires, Sudamericana.

BUENO CHÁVEZ, Raúl (2004): "Sobre la heterogeneidad literaria y cultural en América Latina". Antonio Cornejo Polar y los avatares de la cultura latinoamericana. Lima, UNMSM, Fondo Editorial: 19-35.

FRIERA, Silvina: "Empezamos a cuestionar la figura del «gran padre»". Página/12, el 11 de junio de 2010: https://www.pagina12.com.ar/diario/suplementos/espectaculos/4-18265-201006-11.html (última consulta: 25/10/2017).

GARCÍA CANCLINI, Néstor (1992): Culturas híbridas. Estrategias para entrar y salir de la modernidad. Buenos Aires, Editorial Sudamericana.

HARVEY, Carol: "Dramatising the Romance: from La Manekine to La Fille du roy de Hongrie". Florilegium 19 (2002): 109-125.

KRISTEVA, Julia (1988): Poderes de la perversión. Buenos Aires, Catálogos Editora.

MERUANE, Lina (2010): Las Infantas. Buenos Aires, Eterna Cadencia.

NANCY, Jean-Luc (2007): El intruso. Buenos Aires, Amorrortu Ediciones.

NOGUEROL, Francisca (2001): "Para leer con los brazos en alto: Ana María Shua y sus versiones de los cuentos de hadas". El río de los sueños: aproximaciones críticas a la obra de Ana María Shúa. Ed. Rhonda Buchanan. Washington, OEA: 195-204.

--- (2006): "Luisa Valenzuela: relatos integrados en el infierno de la escritura". El ojo en el caleidoscopio. Coords. Pablo Brescia y Evelia Romano. México, Universidad Nacional Autónoma de México: 389-412.

PUNTE, María José (2013a): "El deseo crece: para una lectura queer de Las Infantas de Lina Meruane". Ponencia presentada en el I Congreso Internacional: Nuevos Horizontes de Iberoamérica, Cuyo, Argentina.

---: "El retorno a los bosques encantados: infancia y monstruosidad en ficciones del sur". Aisthesis 54 (2013b): 287-301.

SARDUY, Severo (1974): Barroco. Buenos Aires, Editorial Sudamericana.

--- (1987): Ensayos generales sobre el barroco. Buenos Aires, Fondo de Cultura Económica.

SOBREVILLA, David: "Transculturación y heterogeneidad: avatares de dos categorías literarias en América Latina". Revista de crítica literaria latinoamericana 54 (2001): 21-33. DOI: https://doi.org/10.2307/4531171

VALENZUELA, Luisa (1999): Cuentos completos y uno más. México, Alfaguara. 
VOIONMAA, Daniel Noemi: "Con Sangre en el ojo: para una escritura de resistencia". Amerika. Mémories, identités, territories 7 (2010): http://amerika.revues.org/3389 (última consulta: 25/10/2017). DOI: https://doi.org/10.4000/amerika.3389

(C) Nerea Oreja Garralda

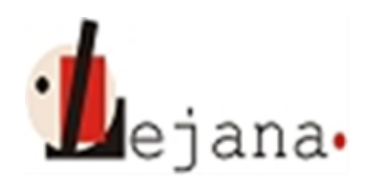

http://ojs.elte.hu/index.php/lejana

Universidad Eötvös Loránd, Departamento de Español, 1088 Budapest, Múzeum krt. 4/C 